\title{
Review on nutritional limitations and opportunities of using rapeseed meal and other rape seed by- products in animal feeding
}

\begin{abstract}
The worldwide increasing demand for proteins as human nutrition and animal feeding leads to a growing interest on other protein sources. Therefore, rapeseed as an established raw material for the production of edible oils could be a promising alternative protein sources for animals. Mustard seed or rapeseed meals are one of the major protein sources for animals in most parts of the world. The utilization and marketing of these rapeseed meals is very limited due to the presence of anti-nutritional factors in the form of mainly Glucosinolates and erucic acid. But there are still a lot of techniques which reduces the Glucosinolates content to a substantial level and made available as protein source in the diets of livestock and poultry. Therefore, the purpose of this review paper is to identify the limitations and explore the opportunities of using rape seed meal/cake in livestock and poultry diets and propose a recommendation for better use of the resources. The antinutritional factors in rapeseed can be reduced by a number of techniques including physical, chemical, biological and crop breeding. But their efficacy varies from one treatment method to the other. Amongst these, crop breeding is the most effective one which is followed by solvent extraction of oil which does not affect the nutritional composition of the feed. Ruminant animals are less susceptible to glucosinolates and other anti-nutritional factors than mono gastric animals. Conventional rapeseed meal can be included up to $10-15 \%$ in broiler diets and $7-8 \%$ in layers diets and can replace up to $50 \%$ of the soybean meal. But canola seeds can be used up to $20 \%$ in compound feed formulation and replacing $25-30 \%$ of the dietary soybean meal in layers ration without significantly affecting laying performance. This low glucosinolate rapeseed meal can be used freely as soybean meal in the diets of ruminants and up to $20 \%$ in broiler diets and 15 in finishing pigs diets. But for better use of these products, further research on development of varieties, treatment methods, economics of feeding, further investigation on amino acid composition and digestibility of different varieties are very important and introduction and evaluation of canola varieties is required.
\end{abstract}

Volume 8 Issue I - 2018

\begin{abstract}
Tekeba Nega, Yirdaw woldes
Ethiopia Meat and Dairy Industry Development Institute, Ethiopia
\end{abstract}

Correspondence: Tekeba Nega, Ethiopia Meat and Dairy Industry Development Institute, P.O. Box 1573, Bishoftu, Ethiopia,Tel:0025 I 919354278 ,Email tekebanega@gmail.com

Received: November 02, 2017| Published: January 25, 2018

Keywords: anti-nutritional factors, full fat soybean meal, glucosinolates, rapeseed meal, solvent extraction

\section{Introduction}

Mustard seeds (Brassica napus) also know as Rape seeds and oil seed rape is very widely cultivated crop throughout the world as major source of oil and protein meal. ${ }^{1}$ The oil recovery from mustard seed ranges between 38-44\% depending upon the variety and crushing processes. $^{2}$ Rapeseed ranks, third in the world production of other oil seed crops. ${ }^{2}$ The protein of rapeseed has a well balanced amino acid profile and in terms of essential amino acids which is far better than cereals. ${ }^{1,3}$ The remain after oil extraction is used as meal for livestock feed. Despite the significant amounts of highly valued nutrients, use of rapeseed in human diets and in animal feeding has been limited, mainly because both oil and protein in rapeseed are accompanied by certain anti-nutritional factors which limited its use as animal feed called Glucosinolates and others. ${ }^{4,5}$ Glucosinolates are group of sulphur-containing secondary plant metabolites produced mainly in Brassica vegetables. ${ }^{4}$ Glucosinolets themselves are not toxic, however, their hydrolytic products are. Brassica seed meals contain an enzyme myrosinase, which catalyzes the hydrolysis of Glucosinolates to harmful products, including goitrogenic and potential hepatoxic compounds, such as isothiocyanates and thiocyanates. ${ }^{4}$

The seed is primarily cultivated for the extraction of oil, the meal that is remained after oil extraction is protein rich $(30-45 \%)$ and may be used either as high protein feed supplement provided that glucosinolate level is reduced or as organic fertilizer. ${ }^{6}$ As a result of removing the anti-nutritional qualities like glucosinolates by the solvents extraction methods, the nutritional quality of rape seed meal can be improved. ${ }^{6,7}$ Most animal feeding trials showed that, detoxified rapeseed cake can be used as a protein supplement to different animal species depending their age group, production level, and species. ${ }^{1,6} \mathrm{~A}$ number of other studies also indicated that, detoxified rapeseed cake can replace most parts of soybean and nug seed cakes (Niger seed cake) at certain percentage.

Ethiopian mustard seed (Brassica carinata), stands fifth after noug, sesame, linseed and groundnut in total production and area coverage in Ethiopia. ${ }^{8}$ High levels of proteins, suitable amount of essential amino acids, minerals and the bio-availability of these nutrients has given 
mustard/rape seed cake, prime importance as a quality protein sources to be used as animal feed. ${ }^{7}$ However, low palatability of mustard cake is said to be the main problem for its utilization in ruminant diets. This problem is attributed to its glucosinolates content which yield hot and pungent metabolites upon hydrolysis due to the action of endogenous enzymes. ${ }^{3,9}$ As evidenced by Ethiopia spice extraction factory report and, ${ }^{6}$ oil extraction through the use of solvents has proven to be beneficial in improving the feed quality of the oil seed cake produced as by-product. This is as a result of removing the anti-nutritional factors like glucosinolates by the solvents acetone, methanol and ethanol. The technologies are under evaluation at a pilot level in Ethiopia by Ethiopia Spice Extraction Factory. The preliminary result indicated that, the level of glucosinolates reduced significantly as a result of detoxification which was confirmed by standard laboratories (personal communication). Therefore, the purpose of this review study is to assess the pros and cones of using rape seed meal and/or rape seed by-products containing diets on the performance of different livestock species including poultry and propose recommendations for further use.

\section{Global overview of rapeseed production and use}

Mustard seeds (Brassica Napus) also known as Rape, Oilseed rape, Rapeseeds and Canola are very widely cultivated throughout the world..$^{10}$ The seeds can come from three different plants: black mustard, brown Indian mustard, and white mustard. Mustard seed is the third leading source of vegetable oil in the world after Soya bean oil and palm oil. ${ }^{7,11}$ It is world's second leading sources of protein meal after soybean meal Rymer. ${ }^{7}$

Global production of rape seed increased from 37.33million tons in 2000 to 59.38 million tons in $2009 .{ }^{10,11}$ With an annual harvest of a little over 450 million tons, oilseed production accounts for just $20 \%$ of the world grain production. ${ }^{10}$ The major contributors to global rape seed production are China, India, EU-27, Canada and others with the share of $22 \%, 11 \%, 36 \%, 20 \%$ and $11 \%$, respectively. ${ }^{10}$ Annual export trade of rapeseed stands at around 12 million tons. In temperate climate like UK, oilseed rape is the only commercially viable crop that provides edible oil. ${ }^{12,13}$ The rapeseed meal that is produced by the extraction of this oil is the major locally produced high protein feed for livestock. ${ }^{12}$ The use of whole oilseed rape in the diets of livestock has also increased in recent years, as the oil provides a concentrated source of energy. ${ }^{7}$ According to Patrick, ${ }^{11}$ rapeseed meal is the second major oilseed meal produced worldwide (after soybean meal) and its consumption has grown strongly in the EU (which is deficient in protein feed), in China (due to its extraordinary economic development), and in USA (due to milk producers' demand for the feed). The main exporters of rapeseed meals in the world are Canada and India. ${ }^{11}$

\section{Nutritional profile and feeding values of ra- peseed meal}

\section{Nutritional composition}

Rapeseed meal is an excellent protein source owing to its relatively high protein level (30-40\%), Lysine, Methionine and Tryptophan levels. ${ }^{1,14-16}$ But the protein from rapeseed meal is less digestible than that of soybean meal ( $72 \%$ vs. $88 \%$ ), but the amino acids balance is similar, even better than in the soybean meal (for the sulphur amino acids). ${ }^{17}$ The Calcium, Phosphorous, Selenium, Iron and Manganese contents in rapeseed meal are very high, but up to $65 \%$ of the P content is abound in P-phytate and this reducing its bioavailability. ${ }^{3,14}$ The high levels of nicotinic acid and Choline as well as low Carotenoid and vitamin D levels are the main vitamins characteristics of rapeseed meal. ${ }^{718}$ The amino acid content of RSM is comparable well with that of soybean meal and richer in Methionine $e^{1,3}$ as indicated in Table 1. The composition of Rapeseed meal and cake varies with the variety, growing conditions and processing methods as indicated in Tables 1 $\& 2$. According to Swati et al. ${ }^{16}$ the crude protein content varies from $33-40 \%$ of which $80-83 \%$ is true protein with appreciable proportion of albumin, glutelin and globulin. The protein is rich in lysine and sulphur containing amino acid which are limiting in cereal protein, making it excellent complementary to cereals based diets Swati et al. ${ }^{16}$ Rape seed protein has a high biological value due to its nearly optimal amino acid composition; however the digestibility of the meal is relatively low, since the proteins are more or less strongly bound to dietary fibers Bellostas et al. ${ }^{19}$

Although the protein quality of rapeseed meal matches that of the soybean meal, certain essential amino acids, particularly lysine is observed to have a lower bioavailability than that of soybean meal because of the occurrence of mallard reaction during rapeseed processing into cake/meal. ${ }^{18}$ The mean amino acid bioavailability of rapeseed cake, rape seed meal and low-temperature processing cake were also found to be $84.02 \%, 86.29 \%$ and $90.82 \%$, respectively. ${ }^{19}$ The lysine bioavailability of low temperature processing cake and rape seed meal were $89.1 \%$ and $73.3 \%$, respectively. The amino acid profiles of both Full Fat Rape Seed and Full Fat Soy Bean, is lower as compared to their respective meals and cakes as indicated in Table 2. This may be related to the higher fat content that occupies most of the volumes of each of the ingredients.

\section{Feeding values of rape seed meal}

Rape seed meal is used as a feed for cattle, poultry and aquatic animals; however, the information on percentage of feed to be given is scant and variable due to a number of limitations. ${ }^{16}$ In case of sheep and goats, mustard cake do not affect feed intake, feed efficiency, nitrogen balance, mineral balance and growth performance of growing lambs. ${ }^{16}$ The effect of feeding mustard cake to fish at a level of 20 to $30 \%$ resulted in abnormalities in liver, congestion and cytoplasmosis in Indian major carps and an inclusion rate of $10 \%$ was found suitable. ${ }^{24}$ If un-detoxified rapeseed meal containing the antinutritional agents is used in chicken rations, sever struma, bleeding of liver may happen. ${ }^{18}$ According to this author, the common rapeseed meal is not usually used in formulating diets for young chickens. In the case of broiler chicks, up to $10-15 \%$ inclusion is possible but for the laying birds, $7.5-8 \%$ of rapeseed meal in the diet is suitable, but at $12 \%$ level inclusion, it will reduce egg weight as well as the rate of hatch. ${ }^{18}$ Rapeseed meals with high content of glucosinolates lead to iodine deficiency disorders of young chicken. ${ }^{18}$

On the other hand, feeding of mustard cake to layers indicated that, egg weight, shell thickness and yolk quality were affected adversely only upon $15 \%$ mustard cake inclusion, but the albumen quality started showing deterioration even at $10 \%$ inclusion itself. ${ }^{3}$ Rapeseed meal can be included in the animal feed to an extent that ensures total glucosinolate level to be below $1-1.5 \mathrm{mmol}$ per $\mathrm{kg}$ of diet. ${ }^{3}$ This level can be considered safe for most mono-gastrics, although it can be subject to variations depending on structural types of glucosinolates, age of the animal and species. ${ }^{3}$ Ruminants can accept much higher levels in their feed as compared to mono-gastrics. ${ }^{18}$ On the other hand, 
Fenwick \& Cruits ${ }^{25}$ indicated that inclusion of rape seed meal more than $10 \mathrm{mg} / \mathrm{kg}$ of total glucosinolates is toxic to pigs and poultry and it is responsible for poor growth and lower thyroid hormone levels in ruminants. ${ }^{26-28}$

Table I The Amino acid profiles of Rape Seed Meal and other oil seeds and by-products

\begin{tabular}{|c|c|c|c|c|c|c|c|c|c|c|c|}
\hline \multirow{2}{*}{$\begin{array}{l}\text { Feed } \\
\text { source }\end{array}$} & \multicolumn{10}{|c|}{ Amino acid profile on dry matter bases (\%) } & \multirow[b]{2}{*}{ Reference } \\
\hline & $\begin{array}{l}\text { Aspartic } \\
\text { acid }\end{array}$ & Threonine & Glycine & Alanine & Valine & Methionin & Leucine & Histidine & Lysine & Argnine & \\
\hline RSM & 2.1 & 1.61 & 2.58 & 1.69 & 1.83 & 0.7 & 2.55 & I & 2.12 & 2.11 & Thanaseelaan ${ }^{3}$ \\
\hline RSM & 2.54 & 1.65 & 1.81 & 1.64 & 1.87 & 0.72 & 2.51 & 1.12 & 2.19 & 2.15 & Rymer $^{7}$ \\
\hline SBM & 5.68 & 2.05 & 8.79 & 2.26 & 2.88 & 0.69 & 4.04 & 1.57 & 3.34 & 3.9 & Rymer $^{7}$ \\
\hline FFRS & 1.63 & 0.94 & 1.08 & 0.94 & 1.14 & 0.48 & 1.45 & 0.63 & 1.32 & 1.35 & Rymer $^{7}$ \\
\hline FFSB & 1.63 & 0.94 & 1.64 & 1.66 & 1.95 & 0.48 & 2.96 & 1.28 & 2.42 & 2.78 & Rymer $^{7}$ \\
\hline $\mathrm{CM}$ & 2.53 & 1.48 & 1.81 & 1.57 & 1.91 & 0.69 & 2.54 & 0.99 & 1.99 & 2.14 & Tanawong $\mathrm{M}^{22}$ \\
\hline RSC & - & 1.34 & - & - & 1.57 & - & 2.23 & 1.16 & 1.62 & 1.78 & $\begin{array}{l}\text { Thacker \& } \\
\text { Petri }^{23}\end{array}$ \\
\hline
\end{tabular}

Note: RSM, rape seed meal; RSC, rape seed cake; FFRS, full fat rape seed; SBM, soybean meal; FFSB, full fat soybean; CM, canola meal

Table 2 Nutritional composition of Rape seed meal and others from different sources

\begin{tabular}{|c|c|c|c|c|c|c|c|c|c|c|c|}
\hline \multirow{2}{*}{$\begin{array}{l}\text { Feed } \\
\text { Type }\end{array}$} & \multicolumn{10}{|c|}{ Chemical composition of rape seed meal and others in \% } & \multirow{2}{*}{ Reference } \\
\hline & Dm (\%) & $\mathbf{C P} \%$ & EE\% & CF\% & NFE\% & ASH\% & NDF\% & ADF\% & $\mathrm{Ca} \%$ & TP\% & \\
\hline RSM & 88 & 38.6 & 1.4 & 11.8 & 28.9 & 7.3 & 20.7 & 16.8 & 0.65 & 1.02 & Feng $^{18}$ \\
\hline RSM & 89.9 & 40.2 & - & II.I & - & - & 29.5 & 20.6 & - & - & Rymer $^{7}$ \\
\hline RSM & 90.8 & 34.9 & I.I & 9.14 & 38.5 & 7.1 & - & - & I.I & 0.68 & Thanaseelaan ${ }^{3}$ \\
\hline RSC & 95.3 & 36.1 & - & 13.1 & 32.2 & 7.1 & - & - & 0.7 & I & Leming $^{20}$ \\
\hline SBM & 88.6 & 49.3 & - & 7 & - & 2.7 & 12.5 & 9.1 & - & - & Rymer $^{7}$ \\
\hline RSC & 86.3 & 28.5 & 14.9 & 12.2 & 34 & 10.4 & - & - & - & - & Jahan et al. ${ }^{21}$ \\
\hline CM & 89.9 & 38.1 & 3.82 & 9.54 & - & 7.33 & 30.7 & 18.5 & 1.34 & 1.15 & Tanawong $\mathrm{M}^{22}$ \\
\hline RSC & 93.1 & 33.9 & 12.4 & - & - & 6.57 & 29.6 & 18.2 & 0.58 & 1.01 & Thacker \& Petri ${ }^{23}$ \\
\hline
\end{tabular}

Note: RMS, rape seed meal; RSC, rape seed cake; SBM, soybean meal; CM, canola meal

\section{Replacement values of rapeseed meal to other pro- tein sources}

According to Tripathy et al. ${ }^{29}$ partial replacement of soybean meal by mustard cake amounting $80 \mathrm{~g} / \mathrm{kg}$ diet had no adverse effects on growth and health of growing rabbits. De-oiled rape seed meal appears to be the potential source of replacing ground nut cake in poultry ration. ${ }^{3}$ Rape seed meal can be used in compound feeds formulation for broilers replacing up to $25 \%$ of the soybean meal without affecting broiler performance. ${ }^{14}$

When rapeseed meal is replacing soybean meal in broiler starter and finisher ration in the following proportions order (0:30 (T1); 7.5:22.5 (T2); 15:15 (T3); 22.5:7.5 (T4); 30:0 (T5) Total Dry Matter Intake (g/bird) DMI), Total Body Weight Gain (BWG) (g/bird) and ME intake (kcal/day/bird) for both starter and finisher phase indicated that as more level of rape seed meal is replacing soy bean meal, the Total Body Weight Gain; ME intake and Total Dry Matter Intake (DMI) declined in a similar fashion as indicated in (Figures 1 \& 2). ${ }^{30}$ As the level of RSM is increasing in the diet, Total Dry Matter Intake and Total Body Weight Gain decreasing accordingly in broiler finishers as well.

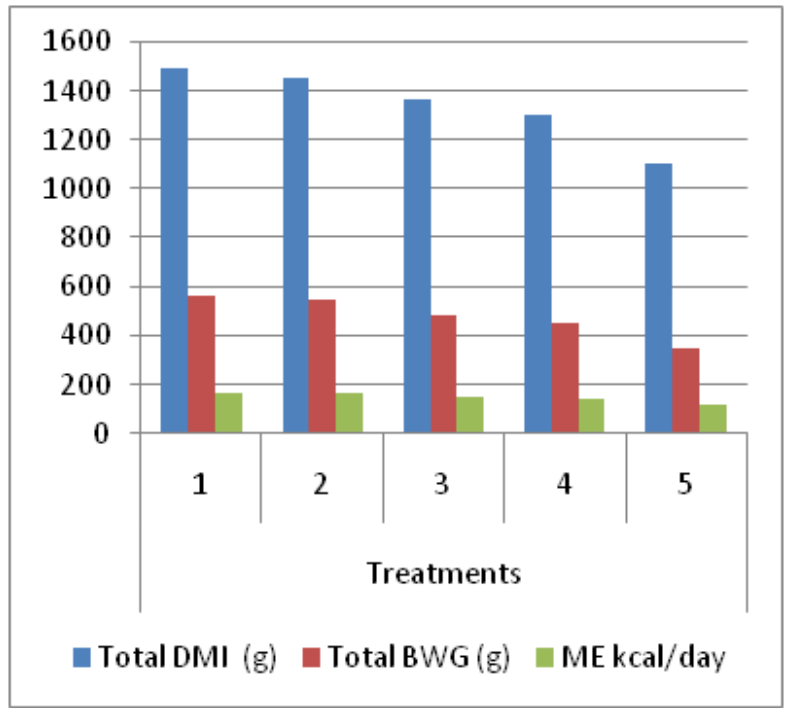

Figure I Effect of SBM replacement with RSM on broiler starter. Source: Endeshaw et al. ${ }^{30}$ 
Similar study made by Tazar et al., ${ }^{15}$ using RSM as a replacement of SBM in male broiler chicks rations in the ratio of $0: 100 ; 25: 75 ; 50: 50$; $75: 25 ; 100: 0$ indicated that the size of the liver and relative weight of gallbladder increased with increasing dietary rapeseed meal. So the study concluded that $25 \%$ of soybean meal can be replaced with rapeseed meal in the diets of broiler chicks without compromising their performance.

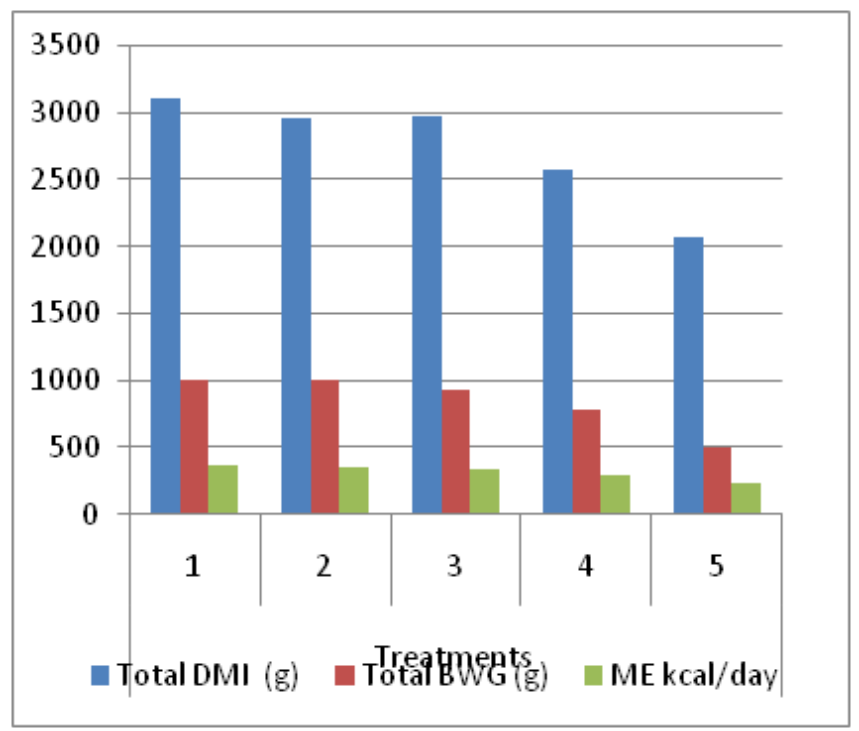

Figure 2 Effect of SBM replacement with RSM on finisher.

Source: Endeshaw et al. ${ }^{30}$

\section{Anti-nutritional factors their effect on production and productivities and treatment methods}

The anti-nutritional factors, which exert adverse effect on growth, health and general welfare of animals, do so through variety of approach to affect digestion, absorbance and availability of nutrients in the feedstuffs. ${ }^{31}$ Although the nutritional value of rapeseed meal is approximate to soybean meal, the application of rapeseed meal is practically limited due to the high levels of some harmful substances as well as many anti-nutritional factors such as glucosinolates, sinapine and its derivatives, tannin, phytic acid, crude fiber etc. ${ }^{31}$

Glucosinolates and sinapine are considered to exert the most effect in terms of the application of rapeseed. ${ }^{18}$ Glucosinolates, generally exists in the potassium salts form, which include glucosinolates and glucoside. ${ }^{18,32}$ Glucosinolates, commonly referred to as goitrogens, are uniform class of naturally occurring compounds found exclusively in the plant kingdom, and only in limited number of dicotyledonous families. ${ }^{15,33}$ The products of hydrolysis of glucosinolates with endogenous thioglucosidase, particularly oxazolidine thione, thiocyanate, isothiocyanate and nitriles are considered to be more harmful than the intact glucosinolates. ${ }^{34}$ Glucosinolates in rape seed cake may go up to $200 \mathrm{mg} / \mathrm{gm}$, whereas the permissible amount is up to $30 \mathrm{mg} / \mathrm{gm}$ for international standards. ${ }^{15}$

Rape seed meal can be treated for their anti-nutritional factors in a number of ways like physical, chemical, biological and crop breeding. ${ }^{30,35}$ Physical methods include inactivation of myrosinase and shelling, and the former consisted of steam heating, roasting, mircowave treatment and bulking etc. Milling with water can activate myrosinase to reduce the glucosinolates. Drying enhances volatilization of isothiocyanates, while extraction causes glucosinolates to survive by $40-80 \%$ in rape seed meal. ${ }^{36}$ The simplest method of detoxifying rapeseed meal is by immersion in water. The treatment with water (1:6), for 15-20 minutes can decrease glucosinolates by $98 \%{ }^{37}$ Acid and alkaline degradation, metal salts degradation and solvent extractions constitute the chemical methods. Acid and alkaline degradation reduced toxicity when $\mathrm{H}_{2} \mathrm{SO}_{4}, \mathrm{NaOH}$, $\mathrm{KOH}, \mathrm{NH} 3, \mathrm{Ca}(\mathrm{OH}) 2$ were used, however the treatments require heat treatment, expensive and goes with pollution. ${ }^{37}$ The rapeseed meals from acid and alkaline degradation are of poor quality and also affect the palatability by the animal. ${ }^{36}$ In the process of solvent extraction, the solvents including ethanol, carbinol, acetone and water etc decreases lower molecular weight glucosinolates. ${ }^{37}$ Biological methods usually include fermentation using microorganisms and hydrolyzation catalyzed by enzyme to reduce the toxin. ${ }^{36}$ Crop breeding is one way to develop new varieties with low erucic acid and glucosinolates, which is the most successful among the four methods. ${ }^{18}$

Due to continuous breeding and development of new crop varieties, rapeseed products from improved double and triple varieties can be included up to $25 \%$ in a poultry ration without any problem and the difference with soybean become almost negligible. ${ }^{31}$ According to Bellostas et al., ${ }^{19}$ the quality of the seed meal is especially influenced by the processing conditions. A certain level of heating during processing is needed for ensuring inactivation of enzymes, such as myrosinase, lipase and lipoxygenase, so as to avoid the formation of nutritionally unwanted compounds during oil extraction and use of the de-oiled meal Bellostas et al. ${ }^{19}$ Nevertheless, excessive heating can result in glucosinolate degradation, decreased available lysine, decreased protein solubility and reduced protein utilization in monogastric diets Bellostas et al. ${ }^{19}$

\section{Other use of rapeseed meal}

Mustard cake is rich in Nitrogen (4.8\%), Phosphorous $\left(2 \%\right.$ as $\mathrm{P}_{2} \mathrm{O}_{5}$ ) and potassium $\left(1.3 \%\right.$ as $\left.\mathrm{K}_{2} \mathrm{O}\right)$ which are essential requirement to maintain fertility of soil and proper growth of plants fertilizers. ${ }^{38}$ But being organic fertilizer, mustard cake, has got a slow release of nutrients timely to the soil which needs a combined application with other fertilizers ${ }^{38}$ Mustard cake can also serve as natural weedcide instead of inorganic fertilizer which pose health problems to human and other mammals. ${ }^{39}$ According to Boydston et al. ${ }^{40}$ due to the production of Allelochemicals produced during glucosinolates degradation in soil, mustard cake can serve as pesticide and weed suppression agent. Mustard cake in addition to the above characteristics can serve as fermentation medium for the growth of mushroom when it is added as a nitrogen source to rice straw substrate, it increased the yield of mushroom by $50-100 \% .^{41}$

\section{Conclusion}

Mustard cake is used as a feed for cattle, poultry and aquatic animals; however, the information on percentage of feed to be given is scant and variable. In case of sheep and goats, mustard cake do not affect feed intake, feed efficiency, nitrogen balance, mineral balance and growth performance of growing lambs as compared with monogastric animals. The anti-nutritional factors in rapeseed can be reduced by a number of techniques including physical, chemical, biological and crop breeding. But their efficacy varies from one treatment method to the other. Amongst these, crop breeding is the most effective one which is followed by solvent extraction of oil which does not affect the nutritional composition of the diet. Ruminant animals are less susceptible to glucosinolates and other anti-nutritional factors than mono gastric animals. Conventional rapeseed meal can be included up to $10-15 \%$ in broiler diets and $7-8 \%$ in layers diets and can replace up 
to $50 \%$ of the soybean meal. But canola seeds can be used up to $20 \%$ in compound feed formulation and replacing $25-30 \%$ of the dietary soybean meal in layers ration without significantly affecting laying performance. This low glucosinolates rapeseed meal can be used freely as soybean meal in the diets of ruminants livestock and up to $20 \%$ in broiler diets and $15 \%$ in finishing pigs diets. Rape seed meal/ cake can be potentially be used in livestock diets, as one can manage the anti-nutritional factors through different treatment methods.

\section{Recommendations}

In developing countries including Ethiopia, the use of grains and conventional protein source to livestock in most cases not realty. Research on development of new rape seed varieties, treatment method; their efficacy on level of glucosinolates and other antinutritional contents, economics of feeding rape seed meals helps to utilize these non-conventional feed types. Further investigation on amino acid composition and digestibility of different varieties and introduction and evaluation of canola varieties etc is another options. Replacement values of rape seed meals with other oil seed meals using different livestock species and economics of using these products should be studied. The current global experience on rape seed meal feedings and its replacement value should be properly documented and applied. Rapeseed meal storage management to avoid aflatoxin is very important. The experience on solvent extraction method and its economic feasibilities and scale of production should be studied. Extension work on the use of rape seed meal feeding and its safe maximum level of inclusion should be promoted.

\section{Acknowledgements}

Author declares no acknowledgment.

\section{Conflict of interest}

Author declares no conflict of interest.

\section{References}

1. Aurang Zeb. Possibilities and Limitations of Feeding Rapeseed Meal to Broiler chicks. Doctoral Dissertation. Germany: Georg-August University; 1998.

2. Shahidi F. Canola and rapeseed-Production, chemistry, nutrition and processing technology. USA: Van Nostrand Reinhold; 1990. 355 p.

3. Thanaseelaan V. Proximate Analysis, Mineral and amino acid profiles of De-oiled rapeseed meal. International Journal of Food, Agriculture and Veterinary Sciences. 2013;3(1):66-69.

4. Chun Chang T, Brian B. Isolation of intact Glucosinolates from Mustard seed meal to increase the sustainability of biodiesel utilization. The Society for Engineering in Agricultural, food, and biological systems; 2004

5. Mejicanos G, Sanjayan N, Kim IH, et al. Recent advances in canola meal utilization in swine nutrition. J Anim Sci Technol. 2016;58:7.

6. Wondimagegne B, Getnet A, Mengistu U. Feeding Detoxified Ethiopian mustard (Brassica carinata) seed cake to sheep:Effect on intake, digestibility, live weight gain and carcass parameters. Scientific Journal of Animal Science. 2016;5(9):346-352.

7. Rymer $\mathrm{C}$, Short $\mathrm{F}$. The nutritive value for livestock of UK oilseed rape and rapeseed meal. Research Review No. OS14. 2003.

8. Ethiopia: Report on Area and Production of crops (Private peasant holdings, Meher Season), CSA (Central Statistical Agency) of Ethiopia, Statistical Bulletin 584; 2009. 1:17.
9. Bell JM, Tyler RT, Rakow G. Nutritional composition and digestibility by $80-\mathrm{kg}$ to $100-\mathrm{kg}$ pigs of prepress solvent-extracted meals from low glucosinolate Brassica juncea, B-napus and B-rapa seed and of solvent-extracted soybean meal. Canadian Journal of Animal Science. 1998;78(2):199-203.

10. Patrick C, Andre P. Rapeseed market, worldwide and in Europe. OCL; 2014:21(1)

11. Rape mustard seed. NCDEX.

12. Hill R. Rapeseed meal in the diets of ruminants. Nutrition abstracts and reviews (series B). 1991;61:139-155.

13. Smithard R. Full fat rapeseed for pig and poultry diet. Feed compounder. 1993:35-38.

14. Georgeta C. Efficiency of soybean meal replacement by rapeseed meal and/or canola seeds in commercial layer diet. Archiva Zootechnica. 2009;12(1):27-33.

15. Taraz Z, Jalili SMA, Rafeie F. Effects of Replacement of Soybean Meal with Rapeseed Meal on Organs Weight, Some Blood Biochemical Parameters and performance of Broiler chicks. International Journal of Poultry Science. 2006;5(12):1110-1115.

16. Swati Sneha S, Madhusweta D. A brief overview: Present status on utilization of mustard oil and cake. Indian Journal of traditional knowledge. 2015;14(2):244-250.

17. Korelesky J. Improved rapeseed meal or oilseed as a feed for poultry $9^{\text {th }}$ European Symposium on Poultry Nutrition. Jelenia Gora, Poland; 1993. p. 35-53.

18. Feng D, Zuo J. Nutritional and anti-nutritional composition of rapeseed meal and its utilization as a feed ingredient for animal. Guangzhou: College of Animal science, South China Agricultural University; 2003. $265 \mathrm{p}$.

19. Bellostas N, Sorensen H, Sorensen S. Quality of rapeseed meal for animal nutrition and as a source of value-added productsglucosinolates, protein and fibers. UK: Department of Natural Sciences, Faculty of Life Sciences, University of Copenhagen; 2007.

20. Leming R, Lember A. Chemical composition of expeller-extracted and cold-pressed rapeseed cake. 2005.

21. Jahan DA, Hussain L, Islam MA, et al. Comparative study of mustard oil cake and soybean meal based artificial diet for Rohu, Labeo rohita Fingerlinges. The agriculturalists. 2013;11(1):61-66.

22. Tanawong M. Evaluation of the nutritional value of Canola meal, 00-rapeseed meal and 00-rapeseed expellers fed to pigs. Champaign; $\mathrm{PhD}$ Dissertation in the graduate College of the University of Illinois at Urbana; 2013.

23. Thacker PA, Petri D. The effect of canola or mustard biodiesel Press cake on nutrient digestibility and performance of broiler chickens. AsiaAust J Anim Sci. 2009;22(11):1531-1539.

24. Hertrampf JW, Piedad-Pascual F. Handbook on ingredients for Aquaculture Feeds. Netherlands: Kluwer Academc Publishers; 2000. $624 \mathrm{p}$.

25. Fenwick GR, Cruits RFC. Rape seed meal and its use in poultry diets. Anim Feed Sci Technol. 1980;5(4):255-298.

26. Papas A, Ingalls JR, Campbell LD. Studies on the effect of rapeseed meal on thyroid status of cattle, glucosinolates and iodine content of milk and other parameters. $J$ Nutr. 1979;109(7):1129-1139.

27. Kracht WH, Jeroch W, Matzke K, et al. The influence of feeding rapeseed on growth and carcass quality of pigs. European Journal of Lipid Science and Technology. 1996;98(10):343-351. 
28. Tripathi MK. Treatment of rapeseed-mustard meal to remove glucosinolates and its effect on nutrient utilization, growth performance and blood bio-chemical studies in cross-bred cattle. India: GB Pant University of Agriculture \& Technology; 1999.

29. Tripathi MK, Mishra AS, Misra AK, et al. Effects of graded level of high Glucosinolate mustard (brassica juncea) meal inclusion on nutrient utilization, growth performance, organ weight and carcass composition of rabbits. World Rabbit Sci. 2003;11(4):211-226.

30. Endeshaw A, Mengistu U, Alem A. Effects of Different Levels of Solvent Extracted Rapeseed Meal Replacement to Soybean Meal on the Performance of Broiler Chicks. Food Science and Quality Management Journal. 2015:36.

31. Huisman J, Tolman GH. Anti-nutritional factors in the plant proteins of diets for non-ruminants. In: Recent Advances in Animal Nutrition. 1992

32. Daniela Von Der Haar, Klaus M, Stephanie B, et al. Rapeseed proteins-Production methods and possible application ranges. OCL. 2014;21(1):D104.

33. Underhill E, Kirkland D. Glucosinolates in secondary plant products In: Bell EA, Charlwood BV, editors. Encyclopedia of plant physiology, New series. Berlin: Springer-Verlag; 1980. p. 493-511.

34. Wang J, Feng D. Feed hygiene. Xi'an map press; 2000. p. 98-120.
35. Jeroch $\mathrm{H}$, Kozlowski $\mathrm{K}$, Olsztyn. Improving the nutritional value of poultry feed stuffs: the rapeseed products example. Lohmann Information; 2013. 48(2):29-35.

36. Schone F, Kirchheim V, Schumann W. Apparent digestibility of high fat rapeseed press cake in growing pigs and effects on feed intake, growth and weight of thyroid and liver. Anim Feed Sci Technol. 1996;62(24):97-110.

37. Fauduct H., Coic JP, Lessire M. Rapeseed meal upgrading Pilot Scale Preparation of rapeseed meal materials with high or low glucosinolate contents. Anim Feed Sci Technol. 1995;56(1-2):99-109.

38. Ullah MS, Islam MS, Islam MA, et al. Effects of organic manures and chemical fertilizers on the yield of brinjal and soil properties. Journal of Bangladesh Agr U. 2008;6(2):271-276.

39. Brown PD, Morra MJ, McCaffrey JP, et al. Allelochemicals produced during glucosinolate degradation in soil. JChem Eco. 1991;17(10):20212034

40. Boydston RA, Anderson T, Vaughn SF. Mustard (sinapis alba) Seed Meal suppresses Weeds in container-grown ornamentals. Hort Sci. 2008;43(3):800-803.

41. Tuli A, Sethi RP, Khanna PK. Lactic acid production from Whey permeate by immobilized Lactobacillus casei. Enzy Microbial Technol. $1985 ; 7(4): 164-168$. 